\title{
EchoGéo
}

48 | 2019

Illegal cannabis cultivation in the world

\section{Illegal cannabis cultivation in Europe: new developments}

David Weinberger, Michel Gandilhon, Jalpa Shah and Nacer Lalam

\section{(2) OpenEdition \\ Journals}

Electronic version

URL: https://journals.openedition.org/echogeo/17704

DOI: 10.4000/echogeo.17704

ISSN: 1963-1197

Publisher

Pôle de recherche pour l'organisation et la diffusion de l'information géographique (CNRS UMR 8586)

\section{Electronic reference}

David Weinberger, Michel Gandilhon, Jalpa Shah and Nacer Lalam, "Illegal cannabis cultivation in Europe: new developments", EchoGéo [Online], 48 | 2019, Online since 13 July 2019, connection on 31 July 2021. URL: http://journals.openedition.org/echogeo/17704 ; DOI: https://doi.org/10.4000/ echogeo.17704

This text was automatically generated on 31 July 2021.

EchoGéo est mis à disposition selon les termes de la licence Creative Commons Attribution - Pas d'Utilisation Commerciale - Pas de Modification 4.0 International (CC BY-NC-ND) 


\title{
Illegal cannabis cultivation in Europe: new developments
}

\author{
David Weinberger, Michel Gandilhon, Jalpa Shah and Nacer Lalam
}

\section{Introduction}

1 Cannabis is by far the most frequently used illegal psychoactive substance in Europe. According to the European Monitoring Centre for Drugs and Drug Addiction (EMCDDA), $27.4 \%$ of the population (that is, 91.2 million individuals) aged 15 to 64 living in the European Union have tried cannabis at least once in their lifetime (EMCDDA, 2019). In 2017, prevalence rates of use among 15 to 34 -year-olds ranged from as low as $3.5 \%$ in Hungary to as high as $21.8 \%$ in France, with a 2-to-1 ratio of use among males in this age group relative to females (EMCDDA, 2019).

2 To the difference of the United States, allegedly the world's largest cannabis market, where herbal cannabis is by far and large the favored cannabis by-product, Europe is a hashish (compressed cannabis resin) consuming region. This is especially the case in France and Spain where Moroccan hashish is very popular. However, since the early 1990s the growing European demand for marihuana (herbal cannabis) has led to the local development of cannabis cultivation. Cannabis seizures numbers reflect this shift in consumption, with herbal cannabis seizures largely surpassing those of cannabis resin as of 2009. In 2017, European law enforcement organizations have reported 439000 seizures of herbal cannabis, 330000 of cannabis resin and 22700 of cannabis plants (EMCDDA, 2019).

3 This article begins by providing an overview of the current situation in Europe, followed by a historical description that underlines the principal role played by the Dutch hub in disseminating marihuana production to the rest of Europe in the 1980s. We will then examine current players in mass production across Europe, taking into consideration the integral role of small growers and cannabis social clubs. Ultimately we aim to show that the European landscape of cannabis cultivation cannot be reduced 
to a criminal business, and is, in fact, much more complex, with a multitude of actors involved.

4 This article is mainly based on primary sources: qualitative data from interviews conducted in 2009 during an INHESJ research on cannabis cultivation in France and in Europe, and quantitative data from the OFDT-TREND reports. The secondary sources are based on academic literature, reports from the French judicial police (OCRTIS: Central Office for Illicit Drug Traffic Control) and the EMCDDA with which the authors maintain privileged institutional relationships.

\section{The ongoing transformation of the European cannabis supply}

During the last 20 years, the number of cannabis plantations discovered in Europe has increased significantly. If we consider that eradicated cannabis plants could be used to a certain extent as indicators of European production (EMCDDA, 2019), the situation is such that economist Adrian Jansen did not hesitate, already in the early 2000s, to mention a real green avalanche in Europe (Jansen, 2002). What was valid at the time with 1.5 million plants seized is no less relevant today with 3.4 million plants seized on average (EMCDDA, 2015, 2019). In the Netherlands (Korf, 2008) and in the United Kingdom, both trendsetter countries with respect to European marihuana production, according to estimates published in 2008 , local production of herbal cannabis allegedly supplies over $80 \%$ of domestic cannabis consumption, up from $40 \%$ in the late 1990 s (Korf, 2008).

\section{A shift among resin-centric countries}

Even in historically resin-centric countries, such as France, Spain, and, to a lesser extent, Italy, recent cannabis herbal seizures show that the cannabis resin hegemony tends to decrease. In France, in a ten-year time span (1999-2018), hashish seizures declined from $90 \%$ to $74 \%$ of all cannabis by-products seized (OCRTIS, 2019). In addition, since the early 2010s seizures of cannabis plants regularly exceed 100000 versus 50000 between 2005 and 2009 (Masson and Gandilhon, 2018).

7 In Spain, cannabis cultivation has increased with the development of illegal indoor and outdoor cultivation, especially in the south of the country, despite the fact that it is Europe's primary entry point for Moroccan cannabis resin (Alvarez et al., 2016). This increase led to a surge in plant seizures in 2018, with over 1 million plants seized from indoor and outdoor cultivation (up from 724,000 in 2016 and 815,924 in 2017) (DEASRI, 2019). The fact that "Spain has become an important producer of herbal cannabis in Europe" was confirmed by the OCRTIS) (DEASRI, 2018) since Spanish production is not only consumed within the country but is also increasingly exported to foreign markets, including to France with French organized crime groups (OCGs) increasingly sourcing their herbal cannabis from the Catalonia region. In $201890 \%$ of herbal cannabis with known origins seized by the French police came from Spain whereas prior to that most herbal cannabis was imported from the Netherlands (DEASRI, 2019). In Italy, marihuana is increasingly consumed and has become the most seized illicit drug: with an everincreasingly high number of seized plants: 464723 plants in 2016 vs 138013 in 2015 and 121659 in 2014 (EMCDDA, 2018). 
Illustration 1 - Seizures of cannabis resin and herbal cannabis, 2016 or more recent year

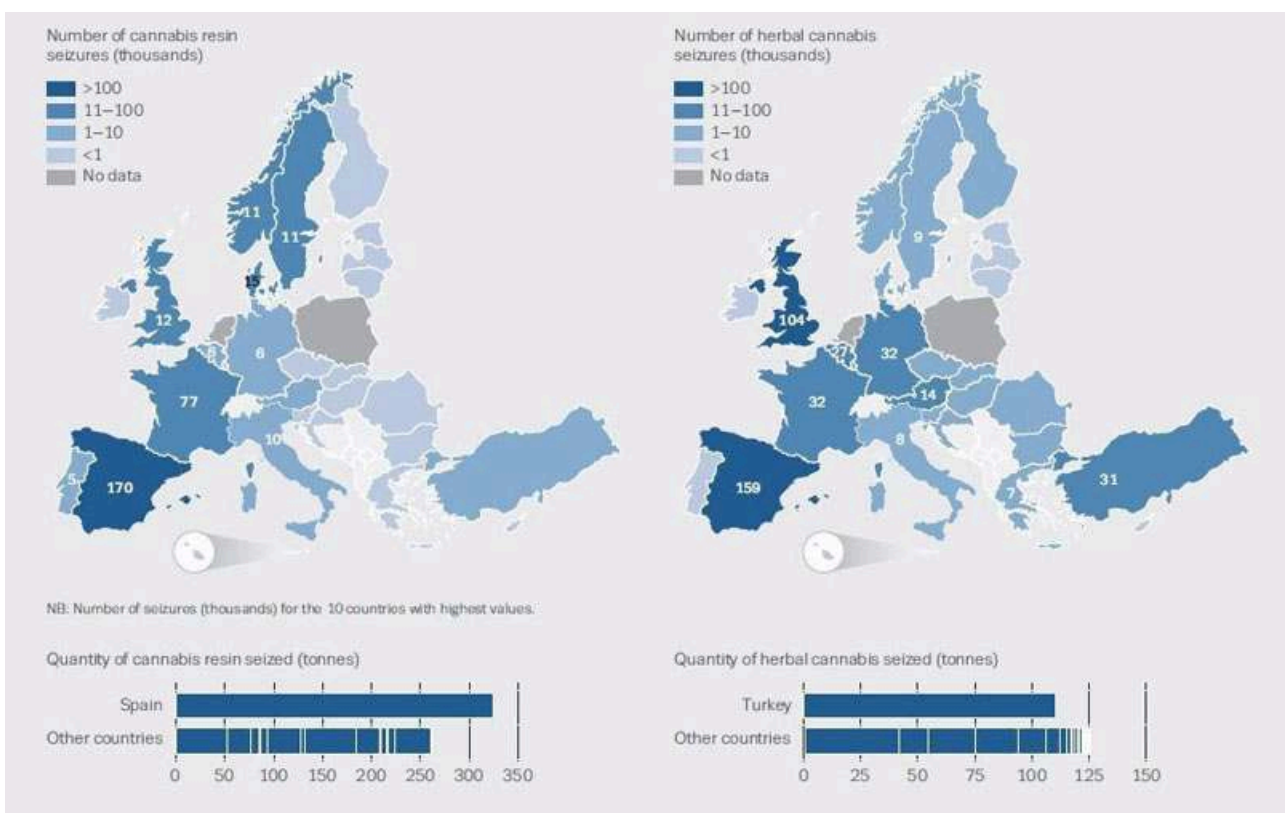

Source: EMCDDA European Drug Report 2018

In Eastern Europe, where Moroccan resin has never been a product of choice, domestic cannabis production ${ }^{1}$ has recently increased, primarily in response to domestic demand, which has reached levels equivalent to those observed in Western Europe. This change stems from a shift in cannabis production and culture from the Netherlands to other EU countries, beginning as early as the 1980s (Potter et al., 2011).

Having reached maturity ${ }^{2}$, the European cannabis market is now increasingly marked by a quest for quality. Quality is determined by the content of the cannabis by-product (marihuana, hashish), by its taste, and by its effect (high), all aspects that depend on the proportion of indica and sativa strains (Ben Lakhdar and Weinberger, 2011). This trend is supported by the listed average prices for product in Europe, where the pergram sales price for high potency cannabis products is 1.4 to 5 times higher ${ }^{3}$ than that of other herbal cannabis varieties (EMCDDA, 2018).

\section{Beginning with the Dutch hub}

\section{The Californian-Dutch connection}

In the early 1980s in Amsterdam, Dutch citizens, such as Wernard Brüning, met Californian cannabis growers, such as David Watson (aka Sam the Skunkman), and shared their breeding and cultivation knowledge and techniques. In the 1960s and 1970s, Californian cannabis growers had started experimenting with hybridization and improved cultivation techniques in order to increase the potency of a Mexican cannabis variety (Weisheit, 1992). The sinsemilla (seedless in Spanish) technique was later adopted, the uprooting of male plants ${ }^{4}$ during cultivation enabling female plants to achieve maximal THC potency ${ }^{5}$. Partnerships between Dutch and American cannabis growers led to a major transformation in the Western European cannabis market. Driven by increasing repression by the Reagan administration as a continuation of 
Nixon's War on Drugs, this "green team", as they called themselves, decided to introduce indoor experimental plantations in Canada and the Netherlands (Decorte, 2010). These growers were able to benefit from a favorable context for their activity: the partial tolerance of cannabis consumption ${ }^{6}$ and the agricultural and indoor horticultural know-how of the Netherlands: new cannabis strains with high THC rates capable of growing in temperate latitudes were created (Brüning, 2003). At the height of the success of their cannabis products, the "green team" opened a shop (the "Amsterdam lowland seed", 1980-84) to sell their new seeds. In 1985, Brüning went one step further and created the Growshop in Amsterdam, selling lamps, seeds, cuttings, and nutrients for indoor cannabis cultivation. By supplying the equipment, seeds and know-how for home cultivation, Brüning's Growshop launched a new trend (Brüning, 2003). Indoor cultivation methods and a new, adapted generation of cannabis seeds were the first step in the development of the European home-grown culture. Made possible through the development of new varieties that could be cultivated indoors, the movement of cannabis production in Europe started to become important in the early 1980 s in the Netherlands. At that time, however, cannabis cultivation remained marginal and only a limited numbers of aficionados were involved in cultivation. This model of cultivation symbolized a time of community-based living and a rejection of consumerist societies. Indeed, these first European cannabis cultivators were usually not interested in a commercial approach. In fact, the cannabis sold in coffee shops was mainly imported, such as resin from Afghanistan, Pakistan, Lebanon, and more marginally from Morocco.

\section{From an inner market to northern Europe}

11 The situation began to change in the mid- to late 1980s with a shift in the consumer market, as an increasing number of users aspired to more potent products that Dutch growers were able to supply. Coffee shops increasingly answered to this demand by offering Dutch products. According to Dutch authorities, about $50 \%$ of the cannabis byproducts consumed in Dutch coffee shops in the mid-1990s were produced locally (Rijswijk, 1995, Jansen, 1991). Today, an estimated $80 \%$ of marihuana sold in Dutch coffee shops is produced in the Netherlands (Nederwiet) (Janssen, 2015).

The booming production of Dutch cannabis was not limited to domestic sales. In the late 1990s, Dutch cannabis production began to be exported to the United Kingdom, Belgium, the Nordic countries, Germany, and some Eastern European countries such as Poland, Hungary and the Czech Republic (Decorte, 2010; Potter, 2008). After successfully meeting local demand (Korf, 1991), the Netherlands become the leading herbal cannabis producing country in Europe and the leading "Eurocannabis" exporter, sending over 500 tons per year to Belgium, Germany and Scandinavia (Lalam and Weinberger, 2010).

\section{An opportunity for Dutch OCGs}

13 Fuelled by the prospect of profit, Dutch criminal networks began specializing in high potency marihuana that could be sold at much higher prices than traditional herbal cannabis. Previously, the majority of these 100 or so crime networks were involved in synthetic drug production - particularly ecstasy. However, they seized the opportunity to increase their profits in the 1980s by setting up indoor plantations in the southern 
Netherlands. The creation of a special "Hemp Task Force" in 2004 has since curbed production via a series of interventions, including the dismantling of cultivation sites, leading to the relocation of Dutch production units from 2006 onwards. Armed with considerable experience in indoor production, these organized crime networks proceeded to develop cannabis factories elsewhere in Europe. Former Dutch producers also reoriented themselves as "consultants" for setting up new plantations, enhancing their technical expertise while providing criminal groups who want to start cultivation sites with the necessary equipment (Korf, 2019).

\section{Controlling the industry}

14 The Dutch criminal networks' growing expertise in indoor production was accompanied by a takeover of the exotic plants legal retail market through so-called "grow shops" specialized in selling the same cultivation equipment needed for indoor cannabis cultivation. These shops now make-up an important component of the criminal networks who own them in the Netherlands and in other European countries. It appears that, among others things, criminal networks fund select shop managers to start cultivating cannabis and to incite exotic plants growers to grow cannabis. Setting up such criminal cooperatives ensures that cannabis production is divided in discrete small- to medium-sized sites that limit losses due to potential seizures or thefts. Grow shops also provide money laundering opportunities to criminal networks ${ }^{7}$. Dutch crime networks have also been investing in grow shops in Spain to spur cannabis cultivation there and in Morocco, to compete with European cannabis (Potter et al., 2016)

\section{Balloon effect: Foreign resettlement and counselling}

15 In response to law enforcement, criminal networks began moving their plantations to the Flemish Region of Belgium. The country has seized about 416,000 plants in 2017 and has become a key player in the European cannabis industry (EMCDDA, 2019). Nearby, Northern France has also been targeted to become a production hub to supply the growing the French market as well as that in other European countries. In 2015, 600 cannabis plants were seized at a French farm operated by a Dutch man, in the Allier department. The equipment required for cultivation had been installed by Dutch organized crime actors, and the products, after passing through the Netherlands, were intended for sale in the United Kingdom (Potter, 2008; Masson and Gandilhon, 2019).

At the same time, OCGs decided to promote their expertise in countries where cannabis cultivation was beginning to draw interest from local players. Certain European police forces have identified the presence of "facilitators" in many countries, including Poland, Czech Republic, Spain, and Morocco (Chouvy and Macfarlane, 2018). In France, it seems that some criminal sectors are increasing cannabis production, as was illustrated with the discovery of a 600 -plant farm in $2007^{8}$. In this case, independently funded cannabis growers received technical assistance from a Dutch investor, while "helping hands" were recruited amongst local dealers. Since then, much more complex methods of trafficking have been uncovered by the OCRTIS, potentially announcing the end of amateurism. For example, a recently dismantled "criminal cooperative" of cannabis nurseries in a dozen houses throughout the French territory mimics a modus operandi previously observed in the Netherlands and Great Britain. In France, the 
decentralization of production creates a higher number of small production sites, relinquishing economies of scale for security.

Then, in a second stage, this trend was "democratized" through the Internet (sharing of expertise online and selling materials and seeds by mail order) as well as through the spread of grow shops in most European countries. For example, a 2013 study on French small growers showed that the ban on the sale of cannabis seeds for cultivation benefited online seed shops. In France, Dutch online grow shops have become the main source of seeds and cuttings (36.2\%), just ahead of traditional trading (purchase, sell, gift) (33\%), and recovery from previous crops (20.2\%) (Boulat et al., 2016).

\section{Contemporary players in European mass production}

From the Netherlands, cannabis cultivation has continued to spread to the rest of the continent, from northern Europe to some of southern Europe. With a market that is increasingly dominated by a variety of transnational networks involved in cannabis cultivation, it would appear that the time of the Dutch monopoly has officially come to an end.

\section{A Vietnamese network: From the United Kingdom through France via Eastern Europe}

The British drug market is often characterized as being at the forefront of new trends and commercial indoor cannabis cultivation appeared there in the late 1980s (Hough, 2003; Potter, 2008). Subsequently, indoor production became a huge phenomenon in the UK, as evidenced by the discovery between 2005 and 2007of 1500 plantations in London alone (SOCA, 2009). Moreover, the British findings revealed that two thirds of the discovered plantations were owned by Sino-Vietnamese criminals9. Laborers in these cannabis farms were primarily recruited through illegal immigration networks (EMCDDA, 2012). As is often the case with prostitution and cigarette trafficking, working on these plantations is one way for immigrants to repay their passage into the country. Meanwhile, organizers come from Sino-Vietnamese communities present in the UK for at least a generation, thus explaining why they are well-integrated into society. Organizers rent the sites, purchase the needed equipment and sell what they produce to British dealers. Profits are often laundered through complex commercial channels in the UK, such as nailbars and Vietnamese companies. Organizations are discreet with well-delineated networks of small plantations. Thus, cannabis production is not handled by a single organization, but rather, a whole host of user-dealer micronetworks based on local and family social ties (Silvestone and Savage, 2011) where trust plays a key regulatory role in production and associated money laundering activities. Such low-key operating methods are very different from the image of a flashy and opulent drug dealer. The ostentatious lifestyle is eschewed and other than exploiting migrant workers for labor, violence is rare ${ }^{10}$ because the purpose is not to control territories, but rather to produce cannabis and sell it to local dealers.

Today, cannabis cultivation remains a key challenge for law enforcement services. In 2016 the United Kingdom seized 340531 plants, one of the highest amounts in Europe (EMCDDA, 2018). However, the current market is changing along with British organized crime landscape: the role of Vietnamese networks is declining in favor of other, local 
OCGs drawn to the profitability of the herbal cannabis market (National Police Chiefs Council, 2014). In turn, an increasingly competitive market is likely responsible for the delocalization of these networks in other European countries such as Germany, the Czech Republic, Hungary, Poland and Slovakia ${ }^{11}$ and France.

\section{France: A market in the making?}

In February 2011, about 700 cannabis plants were discovered in a clandestine indoor plantation located in the Courneuve suburb just north of Paris (Weinberger, 2011). This 'factory' was capable of producing more than $100 \mathrm{~kg}$ of sinsemilla cannabis annually. The people running the plantation could earn over 400,000 euros in sales per year, generating significant profits given the low labor costs. Workers were illegal Vietnamese immigrants who paid for their passage to Europe by working for several months under near slavery conditions (Weinberger, 2011). Since 2011, additional cases involving Vietnamese networks have been uncovered in France, but their role remain marginal when compared to the phenomenon observed in the UK. Alongside SinoVietnamese criminals, a range of other types of criminals are emerging in the French cannabis market, such as gangs specialized in hashish supply who have been reconverting into marihuana production and supply. Some court cases in France have demonstrated that these criminal groups run numerous plantations, set up primarily in the countryside, and supplying dealing retail spot implemented in urban areas (Lalam and Weinberger 2009; Masson and Gandilhon, 2018).

\section{The growing role of mafias}

As is the case in France, the Italian domestic market was historically dominated by cannabis resin. However, an increasing demand for highly-potent herbal cannabis spurred local production at the end of the 1990s, with increased quantities of homegrown cannabis and a larger role played by organized crime groups. This is exemplified by the fact that Italy holds the absolute European record for the largest dismantled plantation, with over 2.5 million plants discovered on a single plantation in 2003. In 2014, an astounding 4 million plants were seized throughout the country, primarily in the south where the climate is most favorable to outdoor cultivation, and where the mafia is very powerful. This is the case in Calabria where cannabis is known as the "green gold of Aspromonte" (the local mountain range) and where a significant portion of Italian cannabis production is concentrated. Here, cultivation is controlled by the 'Ndrangheta crime network, which has been exporting its expertise to Australia since the 1970s, and where outdoor cultivation is still controlled by a few major Calabrian families (Weinberger, 2011). A recent case, in the summer of 2018, illustrates the key role played by this mafia, with 18 people belonging to the Calabrian organization arrested and 26000 plants seized (Euronews, 2018).

The Italian market is also supplied by low-potency Albanian marihuana. Albania started producing cannabis on a commercial scale after the collapse of the Stalinist regime in the 1990s (Zhilla and Lamallari, 2015). The country was so poor at this time that cannabis cultivation spread easily, first to the south of the country (Vlorë, Teplenë, Mallakastër, Berat), then to the north (Shkodër, Tropojë, etc.). Today, a $17 \%$ unemployment rate and an average gross salary of 340 euros highlight a socioeconomic vulnerability that criminal organizations, rather specialized in heroin trade, exploit to 
their advantage. Geographically, Albania is well-situated given its proximity to Italy (as little as $80 \mathrm{~km}$ away in some regions). Despite a much publicized War on Drugs ${ }^{12}$ and frequent cannabis seizures, the Albanian market remains dynamic as reduced exports to Italy have been offset by the opening of the Austrian, Croatian, or even Swedish markets (EMCDDA, 2012).

Between January and October 2017, over 32 tons of herbal cannabis were seized in Albania (versus 30 tons in 2016) and more than 2.5 million plants were uprooted. As a comparison, 89 tons of cannabis herb and 11.4 million plants were seized in the entire EU (DEASRI, 2018). It is noteworthy that, at this time, Albania had become, according to some estimates, the leading producer of marihuana, $1300 \mathrm{t}$ in 2016 versus $900 \mathrm{t}$ in 2015 (DEASRI, 2019), with a high level of products cultivated outdoors in the northern and southwestern mountainous regions of the country. It also appears that a "flight to quality" is underway with an increased cultivation of hybrid cannabis on indoor plantations. Hungary and Slovenia have since reported seizures of the top-quality Skunk strain of cannabis from Albania (Zhilla and Lamallari, 2015). In parallel, the Albanian mafia clans have also distinguished themselves via their capacity to increase production of hashish oil, as discovered in laboratories in Lazarat (Zhilla and Lamallari, 2015). All of the above paint Albania as the new Eldorado for cannabis traffickers, to the point that such production may represent $30 \%$ of the European cannabis market (DEASRI, 2018).

That being said, it would appear that other mafia organizations remain key competitors in the European market. In 2017, a major Chinese network from the UK was dismantled in Spain by the Central Unit for Specialized and Violent Crime (UDEV). Two plantations - out of a total of 12 - containing 2500 marihuana plants were located in Girona and Barcelona. The involvement of Chinese mafias in the marihuana business "has led to a boom in its production in Spain in the last four years. They control the [entire] chain of production, from cultivation to final distribution" thus increasing their profit" (Ortega Dolz, 2018).

\section{The rising of Home Growers}

The growing importance of large-scale commercial cultivation in Europe and the key role played by OCGs in this sector must not obscure the persisting reality of small growers, whether they are individuals or groups, who are essentially cannabis aficionados. In countries like France and Spain, where resin has long dominated the market, small growers and users are moving away from low-quality standardized cannabis by-products, opting instead for niche organic products (INHES, 2009). This trend is not limited to cannabis cultivation and proceeds from a strong desire to control the conditions of production by favoring short supply chains.

\section{Post-1968 France}

The roots of cannabis culture in Europe date back to the counterculture of the 1960s, in the wake of anti-establishment strikes, protests, and civil unrest lead by young people (EMCDDA, 2012). In France, cannabis cultivation took root in the years following the May 1968 events, as numerous youth broke from industrial society, relocating to the countryside, especially in the south of the country. In the 1990s, in a market dominated 
almost entirely by resin from Morocco, and to a much lesser extent Afghanistan and Lebanon, small-scale outdoor grows run by noncommercial growers in France had persisted (Boekhout van Solinge, 1995). A 2009 report on French cannabis cultivation documented how important self-growing was in France (INHES, 2009). Another study showed that people engaged in cultivation out of ecological and self-reliance choices (Lefour, 2006). Despite the growing involvement of OCGs in cannabis cultivation, autonomy and a connection with nature likely remain key motivators for small-scale, non-commercial outdoor growers. The same is true in other European countries, including England and Wales (Hough et al., 2003), Belgium (Decorte, 2010) and Finland and Denmark (Hakkarainen et al., 2011a), where similar motivations were expressed by individual growers.

Free market legalization in some American states has led to the creation of a "green" capitalism (Gandilhon et al., 2018). Commercial models are affecting the cannabis industry. There is a real fear that the non-profit dimension of cannabis cultivation, which remains strong among individual growers and Cannabis Social Clubs (Pardal, 2018), is on its way out in Europe if business friendly models of production prevail. Specifically, small growers are caught between the growing involvement of criminal organizations and a legal accumulation of capital. Nevertheless, the principle of gifting is still very present. In France, the biggest cannabis market in Europe, in 2017, only $35 \%$ of individuals who had consumed cannabis in the past month said that the product they used was gifted to them or obtained through personal cultivation (Spilka et al., 2019). Research shows that the aspect of sharing cannabis persists among many small growers in France (Decorte, 2010; INHES, 2009).

\section{Breaking with criminal markets}

Alongside this dimension, many growers express a desire to avoid the 'criminal element' of the illegal drug market. This was frequently underlined in studies conducted in Western Europe in Denmark, Germany, France, and Finland (EMCDDA, 2012). While the primary motivation is to maintain the security of users avoiding violence and law enforcement, an additional dimension recently emerged in France: a strong desire to avoid contributing to cannabis criminal markets, both out of fear and ethics (Le Parisien, 2012).

Nevertheless, it would be an exaggeration to say that the idyllic pastoral world of cannabis cultivation exists separately from the resin market run by gangs. In France, almost 6 out of 10 small growers are unable to satisfy their needs and are forced to buy from the black market (Gandilhon et al., 2019). Therefore, the era of the Moroccan resin are not over, despite the advent of a much more competitive market. This is especially the case now that the hybrid revolution that has deeply transformed traditional cannabis production has made the production of high quality resin easier and increasingly available (Afsahi and Chouvy, 2015; Chouvy, 2019). Moreover, this fragmented reality of herbal production in France is challenged 'internally' by the growing presence of commercial interests among small growers. 
Illustration 2 - The evolution of average THC concentrations in confiscated resin (STUPS) versus resin voluntarily brought for testing by users (SINTES) from 2000 to 2017

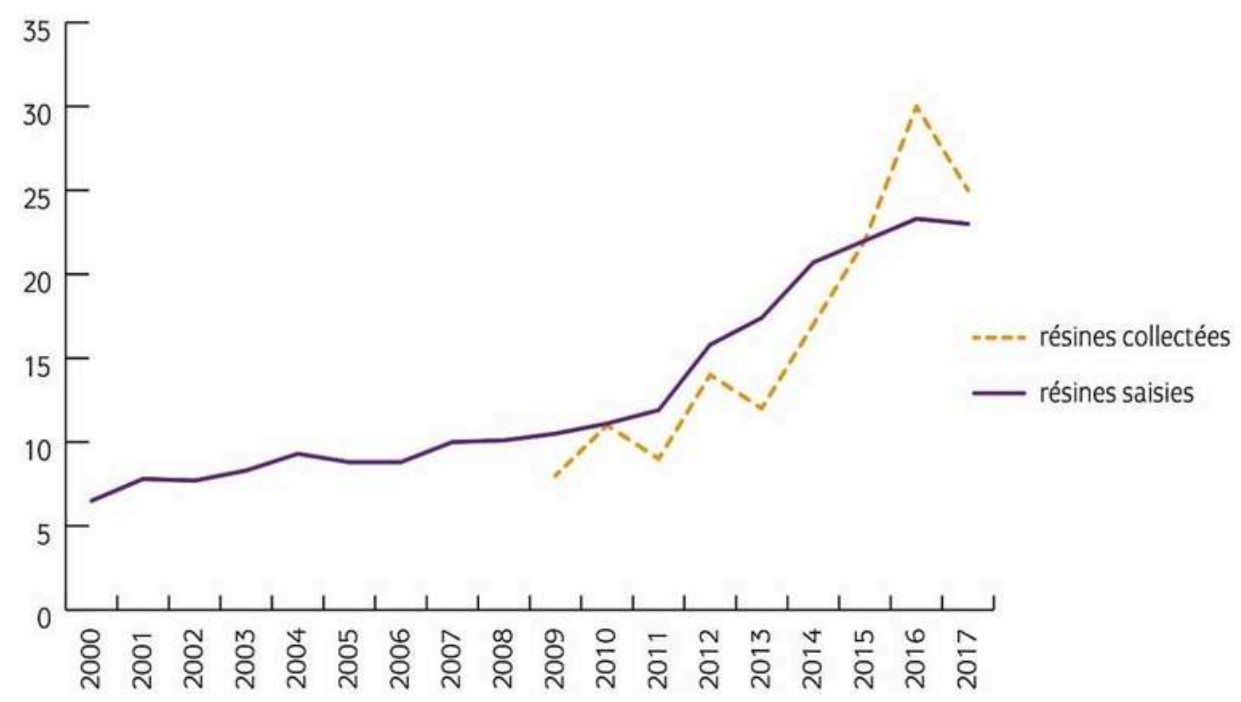

Sources: INPS, SINTES OFDT.

\section{A gray zone: Commercial growing}

Observed across five TREND ${ }^{13}$ sites (Bordeaux, Toulouse, Rennes, Lille and Paris) and by various law enforcement services since 2011, indoor cultivation by individuals has emerged in France without any connection to criminal networks to supply a local market. The development of commercial cannabis cultivation among small-time growers stems from the profitability of the practice in a context marked by an economic crisis. Moreover, a soaring demand for high quality, "organic" cannabis (Obradovic, 2017) and increasing prices ( $€ 5.5$ in 2006 versus $€ 8 / € 10$ in 2017) means that a small installation of 50 plants can generate an annual turnover of approximately $€ 50,000$ (Cadet-Taïrou et al., 2013). Based on continued observations at TREND sites since 2011, it appears that profit-oriented growers are multiplying in France, notably in relation the multiplication of grow shops (MILAD, 2016). However, conclusions regarding small-time commercial growing must be made with caution. First, there has been a concomitant development and growth of an intermediate "craftsmen" category ("artisans") that falls between the "small growers" and "grower-traders" categories. Focused on quality and innovation, craftsmen travel to fairs and markets, especially in the Netherlands, Spain, and the Czech Republic (High Times Cannabis Cup, Spannabis, Cannafest, Konopex, etc.), where they market their products. Second, as demonstrated about Belgium, there is a clear risk in observing the market to overestimate the number of commercial growers due to extensive media coverage and the difficulty that there is to clearly define when exactly cannabis cultivation becomes commercial (Decorte, 2010a). Moreover, a Norwegian study has shown that many practical obstacles block small growers who wish to significantly increase their production, such as a lack of financial means, technicity, and/or retail customers (Hammersvik et al., 2012) 


\section{Conclusion} small-time growers and the attempt to create Cannabis Social Clubs run for non-profit purposes across Europe. The continued presence of non-profit motivations for cannabis cultivation highlights the importance of the principle of gifting, free sharing, and "love" for the plant. Time will tell if this "alter cannabis world" will be a counterweight to the business models coming from OCGs and big corporations (Altria, Novartis, Constellation Brands, etc.), that are positioning themselves in the future European market of legal cannabis (Gandilhon, 2019).

\section{BIBLIOGRAPHY}

Afsahi K., Chouvy P.-A., 2015. Le haschich marocain, du kif aux hybrides. Drogues, enjeux internationaux, $\mathrm{n}^{\circ}$ 8, OFDT [En ligne]. https://www.ofdt.fr/BDD/publications/docs/efdxkav2.pdf

Alvarez A., Gamela J.-F., Parra I., 2016. Cannabis cultivation in Spain: A profile of plantations, growers and production system. International Journal of Drug Policy, vol 37, p. 70-81. DOI: 10.1016/ j.drugpo.2016.08.003

Arana X., Montanes Sanchez V., 2011. Cannabis cultivation in Spain. The case of cannabis Social Clubs. In Decorte T., Potter G., Bouchard M., World Wide Weed. Global Trends in Cannabis cultivation and its control. Ashgate Press, p 162-177. 
Beck S., Cytrynowicz J., 2006. Usages de drogues illicites. Baromètre santé, INPES.

Ben Lakhdar C., 2009. La culture du cannabis en France : implication, volume et qualité estimés. Alcoologie et Addictologie [Online], tome 31, n², p. 121-127. https://www.alcoologie-etaddictologie.fr/index.php/aa/article/view/411

Ben Lakhdar C., Weinberger D., 2011. Du marché du cannabis au marché du THC en France. Implications pour le système d'offre et les politiques de lutte contre les trafics illicites de stupéfiants. Revue Française de socio-économie, n 7, p. 123-145.

Boulat T., Cadet-Taïrou A., Gandilhon M., Néfau T., Lahaie E., 2016. Auto-culture d'herbe de cannabis en France : cultivateurs et production à travers l'enquête SINTES cannabis 2013. Le Courrier des Addictions, vol. 18, $\mathrm{n}^{\circ}$ 4, p. 16-19.

Brüning W., 2003. How to avoid criminalisation of eurocannabis, learning from the dutch experience. Séminaire du CEDRO, Amsterdam.

Cadet-Taïrou A., Gandilhon M., Toufik A., Evrard I., 2008. Emerging Phenomena related to drug use in France in 2006, The eighth national report from the TREND system, OFDT. Tendances, $\mathrm{n}^{\circ} 58$.

Chouvy, P.-A., 2016. The supply of hashish to Europe. Background paper commissioned by the EMCDDA for the 2016 EU Drug Markets Report, Lisbon, EMCDDA.

Chouvy P.-A., Mac Farlane J., 2018. Agricultural innovations in Morocco's cannabis industry. International Journal of Drug Policy, vol. 58, p. 85-91.

Chouvy, P.-A., 2018. Du kif au haschich : évolution de l'industrie du cannabis au Maroc. Bulletin de l'association des géographes, p. 309-321. Bulletin de l'association de géographes français [Online], vol. $95, \mathrm{n}^{\circ}$ 2. http://journals.openedition.org/bagf/3337

DEASRI, 2017. Les réseaux albanais de trafic de stupéfiants. Note $n^{\circ} 11 / 2017$, du 28 décembre, OCRTIS.

DEASRI, 2018. Lutte contre les trafics de stupéfiants en France. Bilan 2017 relatif au cannabis. Note $\mathrm{n}^{\circ}$ 10/2018, 18 juillet, OCRTIS.

DEASRI, 2019. Lutte contre les trafics de stupéfiants en France. Bilan 2018 relatif au cannabis. Note $\mathrm{n}^{\circ}$ 08/20189, 20 juin 2018, OCRTIS.

Decorte T., 2010. The case for small-scale domestic cannabis cultivation. International Journal of Drug Policies, $n^{\circ} 21$, p. 271-275.

Direction centrale de la police judiciaire, 2010. Usage et trafic des produits stupéfiants en France en 2009. OCRTIS.

EMCDDA, 2009-2018. REITOX National Reports: Czech Republic, Germany, Italy, The Netherlands, Portugal, Spain, United Kingdom, Lisbon.

EMCDDA, 2010-2018. Report on the state of the drugs problem in Europe. Annual Report, Lisbon.

EMCDDA, 2012. Cannabis production and markets in Europe. Insight Series, $\mathrm{n}^{\circ}$ 12, $268 \mathrm{p}$.

EMCDDA, 2018. European Drug Report 2017: Trends and Developments. Luxembourg, 90 p.

Gandilhon M., Obradovic I., Lalam N., Alimi D., 2018. Colorado vs Uruguay : deux modes opposés de légalisation du cannabis. Drogues Santé et Société [Online], vol. 16, n 1, p. 70-85. http://droguessante-societe.ca/colorado-vs-uruguay-deux-modes-opposes-de-legalisation-du-cannabis/

Gandilhon M., Spilka S., Masson C., 2019 [à paraître]. Les mutations du marché du cannabis en France : produits, approvisionnement, nouvelles pratiques. Théma, OFDT.

Gandilhon M., 2019. Cannabis : vers l'ère industrielle. Swaps, nº 91, p. 4-7. 
Hardwick S., King L., 2008. Home Office cannabis potency study 2008. Scientific Development Branch, London.

Hough M., et al., 2003. A growing market - the domestic cultivation of cannabis. Joseph Rowntree Foundation.

INHES, 2009. La culture illicite de cannabis en France. Rapport final. Saint Denis, INHES, $127 \mathrm{p}$.

Jansen A. C. M., 1991. Cannabis in Amsterdam: a geography of hashish and marijuana. Muiderberg, Coutinho.

Jansen A. C. M., 2002. The economics of cannabis-cultivation in Europe. 2nd European conference on drug trafficking and law enforcement, Paris, p. 26-27.

Kilmer B., 2017. New Developments in Cannabis regulations. EMCDDA Report, 25 p.

Korf D. J., et al., 2008. Cannabis in Europe: dynamics and perception, policy and markets. Pabst.

Korf D. J., 2011. Marihuana behind and beyond Coffeeshops. In Decorte T., Potter G., Bouchard M., World Wide Weed. Global Trends in Cannabis cultivation and its control. Ashgate Press, p.1-20.

Korf D. J., 2008. Cannabis in Europe: Dynamics in perception, policy and markets, Lengerich, Pabst Science Publishers, p. 69-86.

Korf D. J., 2019. Cannabis Regulation in Europe: Country Report Netherlands [Online]. Transnational Institute. https://www.tni.org/files/publication-downloads/cr_ned_def.pdf

Lalam N., Weinberger D., 2010. La culture du cannabis en France et en Europe. Rapport pour la Mission interministérielle de lutte contre les drogues et la toxicomanie (MILDT), non publié, Paris.

Masson C., Gandilhon M., 2018. Culture du cannabis en France : de l'artisanat à la production industrielle. Cahiers de la Sécurité et de la Justice, n 43, p. 206-215.

Mauss M., 2012. Essai sur le don. Presses universitaires de France.

Ministère de la Santé, du Bien-être et des Sports néerlandais. 1995 [Traduction OFDT, 2005]. La politique en matière de drogue aux Pays-Bas - Continuité et changement. Rijswijk.

National Police Chiefs' Council, 2014. UK National problem profile: Commercial cultivation of cannabis. Report, London.

Obradovic I., 2017. Représentations, motivations et trajectoires d'usage de drogues à l'adolescence. Tendances, OFDT, $\mathrm{n}^{\circ} 122,8 \mathrm{p}$.

Ortega Dolz P., 2018. How Chinese mafias reinvented Spain's marijuana trade. El Pais, Madrid, 2 February. https://elpais.com/elpais/2018/02/02/inenglish/1517575312_291532.html

Pardal M., 2018. An analysis of Belgian Cannabis Social Clubs supply practices: A shapeshifting model? International Journal of Drug Policy, $\mathrm{n}^{\circ}$ 57, p. 32-41.

Potter, G., 2008. The growth of cannabis cultivation/ Explanations for import substitution in the UK. In Korf D.J. (ed.), Cannabis in Europe: Dynamics in Perception, Policy and Markets, Pabst Science Publishers, p. 87-105.

Potter G., Bouchard M., Decorte T., 2011. The globalization of cannabis cultivation. In Decorte T., Potter G., Bouchard M., World Wide Weed. Global Trends in Cannabis cultivation and its control. Ashgate Press, p. 1-20. 
Potter G., et al., 2016. Global patterns of domestic cannabis cultivation: sample characteristics and patterns of growing across eleven countries. In Werse B., Bernard C. (eds), Friendly Business [Online]. Springer VS, Wiesbaden, p. 163-196. https://doi.org/10.1007/978-3-658-10329-3_9

Silverstone D., Savage S., 2010. Farmers, factories and funds: organised crime and illicit drugs cultivation within the British Vietnamese community. Global crime [Online], vol. 11, n 1, p. 16-33. https://doi.org/10.1080/17440570903475683

SOCA, 2009. The UK threat assessment of serious organised crime, year 2008-09. London.

Toufik A., Legleye S., Gandilhon M., 2007. Approvisionnement et prix. In Costes J.-M. (dir.), Cannabis, données essentielles. OFDT.

UNODC, 2018. World Drug Report. Vienne.

Weinberger D., 2011. Criminal networks and indoor cannabis in Europe: has the phenomenon reached France? Drugs, international challenges, $\mathrm{n}^{\circ}$ 1, OFDT.

Weisheit RA. 1992. Domestic marijuana: A neglected industry. Wesport, CT, Greenwood Press.

Zhilla F., Lamallari B., 2015. Organised Crime, Threat Assesment in Albania. Open Society Foundation for Albania, $122 \mathrm{p}$.

\section{NOTES}

1. Domestic cultivation is now reportedly the source of $30 \%$ of the marihuana used in Hungary and Poland, and of more of $50 \%$ of that used in the Czech Republic (2009 National focal points).

2. The diversity of available by-products, the change in prices due mainly to increased THC content and the importance of marketing for certain cannabis products reflect a trend towards prevalence stabilization seen in certain European countries - all signs of a mature market.

3. Average cannabis prices in France vary from $€ 3$ to $€ 10$ per gram of resin and $€ 3$ to $€ 16$ per gram of herbal cannabis. The increase in the price of herbal cannabis has been exclusively linked to Sinsemilla, while resin prices have remained stable and are trending downwards.

4. About $50 \%$ of male plants have to be removed. Now, all-female seeds are available and can be grown without risking male plants, but all-female plants can and will be seeded if male pollen reaches them, especially in outdoor cultivation.

5. With an average of $20 \%$, that can sometimes reach $35 \%$ (Chouvy and Macfarlane, 2018).

6. In the early 1970s, the first coffee shops appeared in Amsterdam, such as Wernard Brüning's Mellow Yellow coffee shop, replacing dealers' houses installed in the "House of youth and culture" at the end of the 1960s.

7. Eurojust coordinated a large case on selling cannabis cultivation tools to foreign buyers: http://www.eurojust.europa.eu/press/PressReleases/Pages/2011/2011-01-27.aspx

8. Interview with the public prosecutor of Nimes and the SRPJ (Police criminal investigation department) of Montpellier (2008).

9. Asian criminal specialization in cannabis cultivation did not begin in Asia, but rather, in Canada, in British Columbia to be specific. British Columbia has had a prevalent SinoVietnamese population since the $19^{\text {th }}$ century (Brochu S., Perras C., (2009). "Le marché des stupéfiants dans une société mondialisée", Rivista di criminologia e sicurezza, vol. III, $\mathrm{n}^{\circ} 3$ \& vol. IV, $\mathrm{n}^{\circ} 1$ ). Along with California and Amsterdam, British Columbia is a key region for the origins of high-THC cannabis cultivation. Aware of the possibilities 
offered by developing sinsemilla, some Canadian criminals of Asian origins supposedly decided to export this method to Europe, specifically to the United Kingdom.

10. This is not the case in the Netherlands, where criminal clashes related to herbal cannabis turf wars caused about 20 deaths in 2009 according to Dutch police authorities at a "Cannabis plant cultivation in France" symposium held in June 2010 in Paris (France).

11. They have their roots in the waves of Vietnamese labor immigration to these countries prior to the collapse of the Berlin Wall.

12. The war on drugs in Albania is guided under pressure from the European Union, who has been using Albania's candidacy to join the EU as impetus for cracking-down on the arrival of drugs from this region.

13. The aim of the TREND scheme of the French Monitoring Center for Drugs, which was established in 1999, is to provide information about illegal drug use and users, and on emerging phenomena. Emerging phenomena refer either to new phenomena or to existing phenomena that have not yet been detected by other observation systems. The system is based on data analysed by eight local coordinating sites (Bordeaux, Lille, Lyon, Marseille, Metz, Paris, Rennes and Toulouse).

\section{ABSTRACTS}

Herbal cannabis is one of the most consumed illegal drugs in Europe, with increasing local production. Illicit cannabis cultivation is not new to Western Europe. It first emerged on the scene in the 1970s, in the wake of the counter-culture following the 1968 Protests. Since then, it has gradually become more professional due to the increased diversification of involved actors, such as Organized Crime Groups (OCG), and the growing role of players linked to mafia organizations in both Italy and Albany. In Spain and France, where Moroccan resin has long dominated supply and demand, the cannabis market has seen a rise in herbal cannabis production. This, in turn, challenges the role of OCGs invested in resin importation. Yet, European marihuana production cannot be defined as a strictly criminal business. Small growers remain significant actors in production. This trend in production must be examined against evolving attitudes towards marihuana at the global level, linked especially to new legislation in the United States and in Canada.

INDEX

Keywords: cannabis, cultivation, Europe, trends, organized crime group

\section{AUTHORS}

\section{DAVID WEINBERGER}

David Weinberger, david.weinberger@inhesj.fr, is a researcher at the French National Institute of higher Studies on Security and Justice (INHESJ). He recently published:

- Gandilhon M., Weinberger D., 2019. The Legalization of Cannabis in the United States and 
Uruguay: Initial Findings. International Journal on Criminology, vol. 6, n 2 . DOI: https://doi.org/ 10.18278/ijc.6.2.2

- Weinberger D., 2018. Afghan opiates along the northern route. UNOCC Report, June.

- Weinberger D., 2017. Légalisation du cannabis et criminalité en Uruguay. Sécurité Globale, vol.4, $\mathrm{n}^{\circ} 12$.

\section{MICHEL GANDILHON}

Michel Gandilhon, Michel.Gandilhon@ofdt.fr, is Head of studies in the French Monitoring Center for Drugs and Drug Addiction (OFDT). He recently published:

- Gandilhon M., Weinberger D., 2019. The Legalization of Cannabis in the United States and Uruguay: Initial Findings. International Journal on Criminology, vol. 6, n 2. DOI: https://doi.org/ 10.18278/ijc.6.2.2

- Gandilhon M., 2019. Colorado: Cannabis Legalization and the Challenge of Organized Crime. International Journal on Criminology, vol. 6, $\mathrm{n}^{\circ}$ 2. DOI: https://doi.org/10.18278/ijc.6.2.3

- Masson C., Gandilhon M., 2018. Culture du cannabis en France : de l'artisanat à la production industrielle. Cahiers de la Sécurité et de la Justice, n 43.

\section{JALPA SHAH}

Jalpa Shah, jalpa.d.shah@gmail.com, is a researcher at Santé Publique France. She recently published:

- Janssen E., Shah J., Néfau T., Cadet-Taïrou A., 2019. Age of Initiation and Patterns of Use among People Who Inject Drugs Welcomed in Harm Reduction Facilities in France from 2006 to 2015. Journal of Psychoactive Drugs, January, p. 1-12. DOI: https://doi.org/10.1080/02791072.2019.1567960 - Milhet M., Shah J., Madesclaire T., Gaissad L., 2019. Chemsex experiences: narratives of pleasure. Drugs and Alcohol Today, vol. 19, $\mathrm{n}^{\circ} 1$, pp. 11-22.

- Shah J., Janssen E., Le Nézet O., Spilka S., 2019. Doping among high school students: findings from the French ESPAD survey. European journal of public health [Online], June. DOI: https:// doi.org/10.1093/eurpub/ckz116

\section{NACER LALAM}

Nacer Lalam, nacer.lalam@inhesj.fr, is head of Studies and research Department at the French National Institute of higher Studies on Security and Justice (INHESJ). He recently published: - Lalam N., 2018. Payback - towards a EU data management system for seized assets. European Project Co-funded by the Internal Security Fund of the European Union, Directorate-General Migration and Home Affairs.

- Lalam N., 2018. L'INHESJ, lieu singulier d'expression du partenariat entre chercheurs et praticiens de la sécurité et de la justice. In Clay T., Fauvarque-Cosson B., Renucci F., ZientaraLogeay S. (dir), États généraux de la recherche sur le droit et la justice. LexisNexis.

- Lalam N., 2018. Le faux monnayage en France, acteurs et organisations. France Forum, n ${ }^{\circ} 71$. 